\title{
Foreign Direct Investment and Its Impact on The Regional Level: A Prospective Analysis
}

\author{
Inversión Extranjera Directa y su Impacto a Nivel Regional: un Análisis \\ Prospectivo \\ Angel G. Atanacio Pérez ${ }^{a}$, Tirso J. Hernández Gracia ${ }^{b}$, Danae Duana Ávila ${ }^{c}$
}

\begin{abstract}
:
Some countries in development like China, the Philippines, Nigeria, Pakistan, Bangladesh, Vietnam and Ukraine do an active promotion in order to raise foreign direct investment (FDI) under the proposal of a positive effect in economic growth while implementing this type of fundraising. Thus, it constitutes an important source of external financing, allowing increases in productivity through technologic transfer as well as rises in competitiveness, efficiency in the managerial models, and expand the countries' exporting capabilities. After the economic crisis experienced in the 80's, Latin America, specifically countries like Argentina, Brazil and Mexico, that have based their financing in loans, stopped to raise money by these means when the crisis appeared, arising as an alternative the FDI, also on account of the foreign creditors demanding the payment of their issued resources and the warning of not giving any more financing until these countries restructure their economies, it was established the capital stock of the recipient economy. In this context, it was necessary to implement structural reforms, which were contemplated in the "Washington Consensus", such as price stabilization and fiscal deficit control with the purpose of recovering the trust to investors and reactivating the capital flow through loans or foreign direct investment aimed at Latin America. In 1990, foreign direct investment became the primary source of external financing to peripheral countries. [1]
\end{abstract}

\section{Keywords:}

Manufacturing sector, regional development, salaries, industries

Resumen:

Algunos países en desarrollo como: China, Filipinas, Nigeria, Pakistán, Bangladesh, Vietnam y Ucrania hacen una promoción activa para la captación de inversión extranjera directa, bajo la propuesta de que la IED presenta un efecto positivo en el crecimiento económico. Por tanto, también constituye una fuente importante de financiamiento externo, permite incrementos en la productividad mediante transferencia tecnológica, así como incremento de la competencia, eficiencia en los modelos de gestión y, amplía la capacidad exportadora de los países. Posterior a la crisis económica experimentada en los años ochenta, América Latina, específicamente países como Argentina, Brasil y México, que habían basaron su fuente de financiamiento en los bancos al entrar la crisis dejaron de recibir recursos, surgiendo como una alternativa la IED, debido a que los acreedores extranjeros exigían el pago de sus créditos erogados y no otorgarían más préstamos hasta que estos países sanearan sus economías, se estableció el stock de capital de la economía receptora. En este contexto, se tuvieron que implementar reformas estructurales, las cuales estaban contempladas en el "Consenso de Washington", como fue la estabilización de precios y el control del déficit fiscal, con la finalidad de que los inversionistas recuperarán la confianza y se reactivara el flujo de capitales, vía créditos o inversión extranjera directa hacia América Latina. En 1990 la inversión extranjera directa pasó a ser la principal fuente de financiamiento externo para los países periféricos. [1]

\section{Palabras Clave:}

Sector manufacturero, desarrollo regional, salarios, industrias

\footnotetext{
aAlumno de la Maestría en Administración, Universidad Autónoma del Estado de Hidalgo, https://orcid.org/ 0000-0002-0630-0683, Email: at280246@uaeh.edu.mx.

b Profesor Investigador del Instituto de Ciencias Económico Administrativas de la Universidad Autónoma del Estado de Hidalgo, programa educativo de administración, https://orcid.org/0000-0003-0425-0800,Email: thernan@uaeh.edu.mx.

${ }^{c}$ Corresponding autor, Profesor Investigador del Instituto de Ciencias Económico Administrativas de la Universidad Autónoma del Estado de Hidalgo, Programa Educativo de Administración, https://orcid.org/0000-0003-2286-2843, Email: duana@uaeh.edu.mx.
} 


\section{Introduction}

The movement of capitals on the international level represented as foreign direct investment has been the subject of multiple reflexions and theoretical approaches in different moments of the time; it is said that investment is a complimentary form of internal savings, however, nowadays, its study, reflection and analysis has gained more importance in political, business and academic discussions; nevertheless, the relative importance of international financing flows is not recent 14 .

So, we could say that foreign direct investment doesn't only have positive externalities or strictly economic benefits given that it might be accompanied by high relative costs to the host country, that is to say, the multinational enterprises could exercise their economic power in the making and application of public policies in order to attempt to avert the entrance of new competitors or to participate in new markets. Or even, non-economic costs turn up, such as cultural nature conflicts in the commodities production and distribution. [2]

The main argument is that benefits are superior to costs, and since the capital is a scarce element in peripheral economies, it is necessary to use, as a final option, the external financing by means of FDI, through promotion policies, generating a rivalry for the pattern triggering resources of this phenomenon. [3]

\section{Main theories and concepts linked to growth and development}

Economic growth refers to the long-term tendency of a country's production, identified by the evolution of gross domestic product (GDP) because it is a measurement relating to the economic activity level of society. Another element to have in mind is the population increase. Only if it is comprehended the population increase, it will be possible to know the changes occurred by the product or rent per inhabitants. For this reason, when studying the economic growth, it is tended to use the GDP scale per inhabitant. The development is a complex phenomenon that includes improvements or economic, political, social and human changes and affects to economic structures as well as political and social institutions. The development is expressed into different levels:

a) Economic: GDP growth per capita, consumption, investment, exports, low inflation and un unemployment rates, infrastructure improvement. b) Social: equitable distribution of national income, significant decrease of poverty, drop of inequality among regions ethnics and sex.

c) Demographic: rise in life expectancy, health improvements and decease prevention, natality decrease.

d) Educational: literacy and elementary education growth, scientific research and technician knowledge accretion, and so on.

e) Political: consolidation of institutions and democratic formulas.

A first approach to understand a region growth emerges from Marshall (1920) as he replied to the next questions: $¿$ Which are the reasons that lead an enterprise to establish itself in one place and do not in another? ¿Can enterprises enjoy the advantages because of the contiguity between themselves? By giving the next response:

There are a lot of reasons that have led to the positioning of industries; but the main ones have a direct relation with physical conditions; for instance: the type of climate, kind of soil and other natural resources which are part of the area where the enterprise is located, or the communication means that provides an easy access by land, air or water. Another motive has been the sponsorship of a group or retinue. The richness simulation creates a demand for, especially, high quality goods, and attracts experienced workers from diverse locations, whoever is educated in along the way. [4]

As a consequence, the growth of the developing regions is a derivative one of the growth effects in the thriving areas, which can be induced by two kinds of effects: favourable and unfavourable. The first one is spread though the demand of advanced regions, including markets for typically primary products of the developing regions; as well as via innovation and investment spreading.

Kaldor (1970), for his part, proposes a variant of the Myrdal's cumulative causation theory, which does uphold the existence of large-scale rising performances (in the broader sense, including external and agglomeration economies) in the manufacturing industry, and quotes rightly the Verdoom's law15. [5] According to the model developed by Kaldor, the regional production growth rates depend on the movement of "efficiency wages" (ratio between a nominal wage rate and a productivity rate), exogenous factors, and the growth rate of the external demand concerning the region productivity, detonating exogenous factor regarding the movement of the cumulative circular process. [6] 
Another approach utilised to explain the regional differentiating comes to notice greatly because of the New Economic Geography, which postulates that regional growth arises from a circular causation logic, in series, backwards and forwards of the enterprises.

The approach of the economic base supported in demand implies a dichotomic economy that distinguishes between basic and non-basic activities. As North (1956) presented it, the central and essential argument means that the regional growth is found itself determined by the basic activities increase of the defined regions like the exporting goods and services producing activities, therefore, they bring monetary abroad resources to the region. In turn, the basic activities growth depends on their producing external demand, furthermore, it is assumed that the growth of nonbasic activities defined as the ones which serve exclusively to either local or regional final and intermediate consuming markets, depends on the achieved demand and the income generated by exportation or basic activities, considering the above it is supposed that non-basic activities have a passive role in the economic growth promotion as it was mentioned by Leven when he pointed out that "the economic basis theory holds up an increase of the non-basic activities and, hence, the production for the local market through a rise of the local revenue, which only can grow if the total external demand of exportable production, and the basic activities, in turn, swell in order that the exogenous change can only and necessarily occur in the exportable sector. [7] [8]

The critiques to the approach based on the demand are focused on its restrictive position of a perfectly elastic offer of supplies, such as labour, capital, imports and public services, that would be available in order to support additional activities of the basic industries at a constant-by unit price, so the offer of supplies is not a restriction to growth. Krikelas, in (1992: 18) developed a detailed analytic story of the theoretical and empirical debates of economic basis theory and states that: "despite the model has improved throughout the years so that it affects additional variables and accepts more explicitly the dynamic nature of the regional growth process, most of the changes have come from within the simple specification field based on demand, the model has not evolved to recognise the potential impact of much more variables that could affect the regional growth. [9]

Thus, a region would grow according to how possible its exporting industries improved their competitiveness with other regions, therefore the economic activities, not strictly basic, perform an important role in the regional growth in proportion with the reliance on the factor costs in exporting industries, the local production or importation replacement could reduce the intermediate supply prices, and decrease the intermediate wages by smaller prices in the consumer goods concerning the imported ones, from the perspective that the exporting basis is a necessary condition, but insufficient for the regional growth.

The Richardson's approach notes the cumulative growth process based on agglomeration economics and also incorporates the space as much between regions as among them, questioning the differentiating importance of agglomeration factors, but it relatively doesn't substitute the first ones for the second ones. Borts (1974) remarked that what started as an attack of neoclassical growth models, finished interestingly, potentially useful and utilisable of the positioning variables that could strengthen the neoclassical approach.

The regional neoclassical economics was developed during the 50's and 60's, in response to the unbalanced growth theories, the neoclassical economics was created on the basis of stable equilibrium theories and shared the assumptions of the trading neoclassical theory, that afterwards Bertil G. Ohlin developed. The theory carried out by Ohlin was based on the hypothesis that free trade of merchandises just as the free capital geographic mobility and other production factors was going to lead to the stabilisation of income from these activities, as much between the countries as between the regions. At the same time, the central assumption of regional neoclassical economics starts on the basis of an hypotheses that regional instabilities are basically provoked for the insufficient territorial immobility of production factors. This one is considered as an obstacle for the free functioning of the market mechanism in a certain territory, and, for that reason, it constitutes an obstacle to create the possibilities of stabilising the salary just like the benefits among different regions.

The mobility of factors faced with the difference in their own prices, the production between the non-agricultural production and the aggregate capital-labour ratio indicates to enterprises that they shall represent a smaller aggregate capital-labour ratio in any production process and will produce a greater marginal value of product to capital, if these are not in low-wage regions; thus while the capital migrates from high-wage regions to low-wage regions, the capital-labour ratios rise in the low-wage regions, reducing the capital profits and increasing the product marginal value of labour.

The neoclassical approach upholds that capital and labour profits in the different regions will converge in the longterm, in general, the mechanism of auto adjustment, which is based on an instability situation, states the hypothesis 
that regions with advantages in costs attract enterprises in a much larger proportion than the rest of the nation and, hence, experiment relatively quick growth rates, but at the same time that the number of enterprises located in that regions increase, costs will increase too, and other enterprises will continue shifting to this region until production costs are similar to other regions. Therefore, balance will be achieved and any differential in the growth rate between regions will be eliminated over time, labour will tend to migrate towards regions with relatively high real wages until these are alike to other regions.

The theory of the exporting basis comes fundamentally from the economic history, and emerges as a reaction to the explanation of the regional growth founded on a sequence of occurrences, which according to this; firstly, regions initiate with an economy of subsistence that comprise scant interaction and commerce; secondly, they improve their transport conditions which allow the development of trading and specialisation; thirdly, their regional economy is diversified due to interregional trading, starting by setting up primary activities, then industrialisation because of the declining profits; and finally the region achieves the tertiary sector and becomes an exporter.

The theory of the exporting basis suggests that, according to the United States (US) experiences, regions do not develop gradually based on auto subsistence, but thanks to the exporting potential. "Many new regions in US develop around one or two exportable goods and expanded their exporting basis just after have reduced their transportation cost. Also, it is criticised their failure to correct their regional instabilities as their lack of ability to encourage the emergence of innovative entrepreneurs at the local level because of an excess regarding the state control and assistance character. These facts have given rise to the emergence of new contributions for regional development strategies, that could be comprehended under the denomination of endogenous development.

In the core periphery theory, it is observed a cumulative impact of evolution and growth concerning the production, labour, capital and knowledge factors, in benefit of regions that were the first ones to develop and the detriment of regions far from them, resulting frequently in what it is called a relation core-periphery. [10]

In almost every industrialised country of the world, it is possible to observe more populated core regions that are the focal point of a major industrialisation and urbanisation, and where revenue is higher than the rest of the country.
In most of the Latin-American countries, excepting notably Brazil where its economic core is still in the south of the country, the region of the national capital shows revenue levels far beyond the national average as, for example, Caracas in Venezuela, Mexico City in Mexico, Lima in Peru, Guatemala City in Guatemala or Montevideo in Uruguay. Once. Once the power of attraction in capital regions is installed in the economic geography of a country, it is very hard to counterbalance this situation. The cumulative causation models explain the growth differentials or polarisation between the centre and the periphery whilst a transitional stage towards a territorial industrialisation and integration of national economies. However, Friedmann recognises the importance of the political and economic instabilities and the differential ratios of cultural changes between regions in the explanations of disparity.

The main problem that is present in this conceptual scheme depends on the intervention of public politics or the surmise of once industrialisation is achieved, the government will look for the interregional fairness and not really for the aggregated efficiency, this is why it arises a questioning of whether conditions to the aforementioned change towards the primary interregional fairness will occur. In the core periphery model, the economic growth proposes to reduce the relative size of the primary sector as a consequence of (I) the low return-demand elasticity of the non-processed assets, (II) the tendency to substitute natural raw materials for synthetic ones in production processes and (III) the rising of efficiency in the primary assets production of their own. The change in the productive structure (manufacturing producer and raw material producer in the centre and the periphery, respectively) operates with a systematic bias against developing regions, tending towards a generation of labour excesses dedicated to the primary activity in the periphery.

\section{Foreign direct investment in Mexico}

The imports substitution model that characterised the national economy as of the mid-30s, disappeared because of the economic crisis in 1982, and it was replaced by an open economics model. The economic political reforms in the mid-80s, as the joining of Mexico into the (GATT) in 1986, the privatisation of public enterprises, legal reforms, among other elements, allowed the implementation of the new paradigm. Furthermore, accompanied by the (NAFTA) in 1994, it was consolidated the opening of the national economy, signing subsequently 10 more agreements in this sense, and considering the reduction of the public sector and a low ability to do household savings, the attraction of (FDI) represented the best option of external financing. Since 2004, in absolute terms, it is presented a positive tendency in the performance of (FDI) 
raising to Mexico, what implied that once the (NAFTA) became effective, helped to underpin the growth of (FDI) in Mexico.

One of the reasons that can explain the performance of FDI in Mexico from 1986 to 1987 is due to the implementation of a loan conversion program, and from 1986 to 1990 a quarter of the received FDI is attributable to the aforesaid program, similarly the upturn of FDI in 1994 could be explain for the perspectives of (EMS)16 concerning the effective date of NAFTA. Otherwise, there are periods of time where FDI was not favourable like in 1998, 2003 and 2009, years in which it is noticeable some decreases compared with the past year. Additionally, the performance of FDI outflows has been almost the same as the observed FDI inflows, but in smaller proportions, supporting the Mexican economy as a net recipient of savings. [11]

\section{Foreign direct manufacturing investment in Mexico, according to the regional growth}

Concerning the regional localisation of FDI, this is characterised by its high grade of concentration in Mexico City, nonetheless, it is inferred that traditional analysis variables, as the GDP and work costs, are not the main explanatory variables of raising neither in the Federal Entities nor in the spatial distribution of FDI in Mexico. As an example of this, Mexico state contributes a greater proportion of GDP to the national economy, compared with Nuevo León, and raises a smaller amount of FDI; on the other hand, Jalisco generates a greater GDP than Tamaulipas, Chihuahua, Baja California, Querétaro, Sonora, Colima and Coahuila, regardless of receiving a smaller amount of FDI, but, particularly in this case and excepting Querétaro, it is probably explained because of the proximity of those countries to the North American market.

In 1995, Oaxaca state registered a drop of 2 million dollar, accompanied by Veracruz state that, in 1999, also registered a fall of 24.9 million dollar. It is intuited that regional differences of total productivity factors trigger the concentration of the foreign investment, on this matter, the quality of structure, the work expertise and the R\&D investment could be explanatory variables to really consider17 as it is displayed in the graphics that shows the FDI in the past ten years. We could say that, in the latest ten years, all the states have suffered a reduction as regards the raising of investment owing to different economic problems that the world economy is going through, such is the case with the states of Campeche, Colima, Chiapas, Durango, Guerrero, Hidalgo, Michoacán, Morelos, Oaxaca, Puebla, San Luis Potosí and Tlaxcala, where 2005 is the most critic year because
5 out of the 12 aforementioned states experienced a major reduction, but Campeche, for its part, underwent annual reductions from 2007 to 2010 .

\section{References}

[1] Aitken, B., y Harrison, E. (1999). Do domestic firms benefit from direct foreign investment: evidence from Venezuela. American Economic Review, 89 (3), p. 605-618.

[2] Safarian, E., (1973). Perspectives of foreign direct investment from the viewpoint of a capital receiving country, The journal of finance, 28 (2), papers and proceedings of the thirty-first annual meeting of the American Finance Association Toronto, Canada, p. 419-438.

[3] Díaz, R., (2001). Un estudio descriptivo de la inversión extranjera directa en España y su distribución territorial. Departamento de Fundamentos del Análisis Económico e Historia e Instituciones Económicas, p. 1-26.

[4] Marshall, A., (1920). Principles of Economics, $8^{\mathrm{a}}$ ed. Macmillan, London.

[5] Kaldor, N., (1970). The case for regional policies, Scottish Journal of Political Economy, 17 (3), p. 337-348

[6] Tamayo, F., (2000) Las Políticas de desarrollo industrial regional y sus nexos teóricos, laissez- faire e iniciativas locales en México, Ed. CIDE, División de Administración Pública, Mexico.

[7] Leven, Ch., (1985) Regional Development analysis and policy, Journal of Regional Science, 25 (4).

[8] North, D., (1956), A reply, Journal of political economy, 64.

[9] Krikelas, A., (1992), Why regions grow: A review of research on the economic base model, Economic review, 77 (4), Federal Reserve Bank of Atlanta.

[10] Carrillo, M., (2002). Aspectos Microeconómicos introductorios del desarrollo regional y urbano, Instituto Politécnico Nacional.

[11] Agosin, M. et Al., (1996) Inversión extranjera directa en América Latina: Su contribución al desarrollo. Santiago de Chile $1^{a}$ edición, Ed. Banco Interamericano de Desarrollo y Fondo de Cultura Económica. 